\title{
The dynamics of forest species composition in the Eastern Moscow Region
}

\author{
Vera Kiseleva ${ }^{1}$, Leonid Stonozhenko ${ }^{1,2} \bowtie$, Sergei Korotkov $^{1,3}$ \\ ${ }^{1}$ Bauman Moscow State Technical University, Mytischi Branch, Institutskaya 1, Mytischi, 141005, Moscow Region, \\ Russian Federation, e-mail: stonozhenko@mgul.ac.ru \\ ${ }^{2}$ All-Russia Institute of Improvement of Professional Skill of Executives and Specialists of Forestry, Insitutskaya 17, \\ Pushkino, 141200, Moscow Region, Russian Federation \\ ${ }^{3}$ Russian Academy of Sciences, Institute of Forest Science, Sovetskaya 21, Uspenskoe, 143030, Moscow Region, \\ Russian Federation
}

\begin{abstract}
The forests of urbanised areas provide multiple ecosystem services and are highly dynamic. Determining the trends in species composition changes can help to predict their future capacity to fulfil ecological and resource-maintaining functions. We examined the direction of forest successions in the Northeast Moscow region under the canopy of different tree species. Field data were obtained from 78 permanent test plots monitored for more than a 15 -year period; field studies were complemented by archival data. The cluster analysis made it possible to divide all plots into five groups by current species composition and structure and into eight groups by the importance of broadleaved species in the undergrowth. Gradual evolution (cohort dynamics) was found to be typical for middle-aged secondary forests; patch dynamics was described in mature stands of late succession species after non-critical natural disturbances; drastic changes were observed in spruce (Picea abies (L.) Karst.) stands after pest attacks. Two main trends were revealed in species composition shift: restoration of mixed spruce-broadleaved forests and development of limedominated broad-leaved forests, the latter being the prevailing one in the stands of composite forest types. Intensive development of oak-associated species is probably related to the climate conditions in the Moscow megacity.

The content of this article may be of interest for researchers studying natural forest dynamics and can be used for prospective planning of target species composition in the forestries of the Moscow region.
\end{abstract}

\section{KeY WORDS}

successions, overstorey, undergrowth, spruce, lime, Moscow region

\section{INTRODUCTION}

Forests of the Moscow region are of a great social importance because they provide multiple ecosystem services. Surrounding the national capital, they should be the example of balanced multi-target forest management.

The forests of the Moscow region lost their original shape a long time ago; their structure and composition have been changed crucially (Rysin 2012). The clearcut- 
ting has been prohibited in the Moscow region since 1940s, and the forest development has proceeded under the effect of less destructive treatments: thinning, selective sanitation felling and landscape-improving cuts in recreational forests balanced by natural processes of stand development. All forests of the region are referred to as protective ones, designated to produce ecosystem services, which are known to depend strongly on species composition (Gamfeldt et al. 2013; Schepaschenko et al. 2018).

The understanding of current and possible future trends in tree species dynamics would help in working out forest management strategies, considering possible climate changes and increasing request for recreational resources. The maintenance of environmental quality and recreational ecosystem services demand the approaches to management, which should be different from those traditionally used for timber production.

The state of forests in the highly urbanised Moscow region is extremely dynamic. The issue of succession trends in the region is still open to question (Maslov 2012; Braslavskaya and Tikhonova 2016; Korotkov et al. 2016). Considering the mosaic structure and 'openness' of the forests, the direction of species succession, according to Abaturov, 'depends on the factors that seem to be stochastic'. Moreover, he concluded that 'no species repeats itself in the next generation' (Abaturov and Melankholin 2004). The latter statement stems from the fact that the environmental conditions in oldgrowth forests can change through the lifetime of a tree generation, thus becoming less favourable for the main species and more favourable for other ones (Sukachev 1972; Connell and Slatyer 1977). In the region studied, this is manifested via soil-vegetation interactions (Martynenko et al. 2018).

The current ratio amongst predominant species in the region in 2010s is the following: birch (mainly Betula pendula Ross.) occupies 39.7\%; spruce (Picea abies (L.) Karst.) 24.4\%; pine (Pinus sylvestris L.) 20.3\%, aspen (Populus tremula L.) $8.6 \%$ and other species, including oak (Quercus robur L.) and lime (Tilia cordata Mill.), $7.0 \%$ of forested lands.

Low forest stability is one of the reasons of dynamics and uncertainty. High percentage of coniferous stands is represented either by cultures or by monodominant and even-aged natural forests of the first generation. Monodominant coniferous forests are not stable because of their primitive structure and lack of undergrowth. The leading role amongst deciduous species belongs to pioneer species, especially to birch. These short-derivative deciduous forests are unstable because of relatively short lifetime of deciduous species. Both are the stands where the change in forest generations can be accompanied by serious shifts in the species composition.

Changes in the patterns of forest exploitation, pestand windfall-induced forest losses and senescence of large forest areas force us to address the issue of forest formation and directions of forest development as related to climate changes and anthropogenic loads.

This work was aimed at following the trends of species composition changes in the forests of the Eastern Moscow region, which comprise a national-level protected area and forests widely used for recreation using both archive data and current observation on permanent observation plots. We set as a goal to understand possible directions of current and future changes, which may help to adjust management practices to natural processes and forecast their consequences in terms of biological diversity and recreational services.

\section{Material AND methods}

The trends of species composition dynamics were studied on permanent observation plots (POPs) located in two forest massifs in the northeastern sector of Moscow region: Losiny Ostrov National Park (55.887786 N, 37.930388 E) and Shchelkovo Experimental Forestry (55.949541 N, 38.125686 E).

The national park borders directly with northeastern districts of Moscow, one-fourth of its territory being included into the administrative boundaries of the capital (Fig. 1). Hence, the dynamics of its forests is controlled by both natural trends and complex anthropogenic impact. Shchelkovo Forestry is situated eastwards from the national park, is more remote from the city and thus less subjected to its complex influence.

According to the map of the Moscow region landscapes (Annenskaya et al. 1997), both forestries belong to the same landscape - the glaciofluvial plain with sandy and sandy-loamy gleyey soddy-podzolic soils on glaciofluvial sediments underlain by moraine. The vegetation is represented by pine, spruce and secondary de- 
ciduous forests with the cover consisting of forbs, oxalis and green mosses. The forests with a large proportion of broadleaved species (oak, lime and Norway maple [Acer platanoides L.]) occur on moraine outcrops. We suppose that the forest-forming processes on both territories should be similar.



Figure 1. Location of groups of studied objects (Moscow and Moscow region)

For the most drained habitats of Losiny Ostrov, the climax forest communities are composite spruce forests (with lime, oak and hazel [Corylus avellana L.]) on moraine hills and forb-oxalis and oxalis-blueberry spruce forests on glaciofluvial plains (Rysin 2012). In Shchelkovo Forestry, the list of conventionally climax community types includes spruce forests of green moss and composite groups.

The observation plots were established in the forests of different species composition, including both conventionally climax and secondary forest types of different habitats: oxalis spruce forests (7 objects); composite spruce and lime-spruce forests with nemoral forbs (14 objects), their derivatives represented by pine and larch (Larix sibirica Ledeb.) cultures (18 and 4 objects, respectively); and birch, lime-birch and aspen forests (18 objects), as well as the forests with the predominance of broad-leaved species (6 oak-predominated and 11 lime-predominated sites). The position of the latter in the succession series is still under discussion. Fiftysix plots in the national park were set in 1998-2000 and have been revised each 5 years up to 2015. Four plots in the Shchelkovo Forestry were set in 2003 and revis- ited in 2013-2014, and the rest 18 were established in 2012-2013.

The observation plots were set and described according to the Russian Industry Standard OST 56-69-83. The minimal number of trees per test plot was 150 , including at least 100 trees of the main species. As a result, the size of the test plots varied from 0.25 to 0.6 ha in Losiny Ostrov and from 0.12 to 0.25 ha in Shchelkovo Forestry, depending on stand age and density. During subsequent observations, we included new trees in the records in case they had reached the minimal diameter at breast height $(\mathrm{DBH})$ of $8 \mathrm{~cm}$. Thinner specimens were referred to as undergrowth.

Each tree within the test plots was characterised by the DBH. Tree heights were measured for model trees, 15-25 per plot, selected to represent different diameter grades. The diameter-height graphs constructed for model trees and approximated by a polynomial equation were used to calculate the heights of all other trees. The maximum, mean and minimum heights of the overstorey and subcanopy were calculated to divide all trees into vertical layers.

The undergrowth was described on test plots with an area of $25 \mathrm{~m}^{2}$, five test plots on each POP, situated in the centre and at the corners of the POP. The undergrowth was recorded by species and size categories (small, below $0.5 \mathrm{~m}$; medium, between 0.5 and $1.5 \mathrm{~m}$; and high, above $1.5 \mathrm{~m}$ ), with the following recalculation per unit area (hectare).

To follow the general trend in stands' evolution, tree species were united into four groups: pioneer deciduous (birch and aspen), light coniferous (pine and larch, the latter being of cultural origin only), late succession broadleaved (oak, lime, maple, elm [Ulmus glabra Huds.] and ash [Fraxinus pennsylvanica Marsh.]) and dark coniferous (spruce).

In order to arrange the totality of studied objects by species composition, we used the cluster analysis, which was shown to be efficient in vegetation classification (Douda et al. 2015) and soil cover studies (Karminov and Martynenko 2007). Thirteen variables were selected: canopy age; stock volumes of pioneer; light coniferous, dark coniferous and late succession broadleaved species in canopy and subcanopy layers $\left(\mathrm{m}^{3} / \mathrm{ha}\right)$; and the number of undergrowth of these groups (specimens/ha).

In order to evaluate general trends in species dynamics in studied forestries, archive data of previous 
forest surveys considering the areas of predominating species were examined. These data were available since 1934 for the national park and since 1947 for Shchelkovo Forestry.

\section{Results}

\section{Retrospective analysis of species ratios in the studied forestries}

Figure 2 represents the average species composition of the two territories in different years. The situation in Losiny Ostrov is clearly more dynamic than in Shchelkovo Forestry. Over the past century, the dominant role has moved over to secondary deciduous forests. The proportion of pine is maintained artificially by creating pine plantations; the proportion of spruce is maintained both because of plantations and by progressing change of early succession species by late succession ones. At the same time, the proportion of the areas occupied by lime-dominated forests gradually increases; this fact has not been observed until the middle 20th century (History and state... 2000). High proportion of lime forests in the total area of forested lands is specific for Losiny Ostrov, unlike other forests of the Moscow region.

The species proportions in the Shchelkovo Forestry is more stable (Fig. 2), although the proportion of pine increased because of cultivation, whereas aspen has been gradually removed by reconstructive cuts as a non-desirable species.

The situation persisted until 2010-2012 when large spruce forest massifs died, being affected by spruce bark beetle (Ips typographus L.). The area of dead monodominant spruce forests in Losiny Ostrov alone



Figure 2. Average species composition of Losiny Ostrov National Park and Shchelkovo Experimental Forestry, according to forest survey data and $\%$ of total forested area 
exceeded 400 ha, apart from 450 ha of partially affected composite forests. Four observation plots were significantly damaged by bark beetle; their dynamics is examined separately.

\section{Trends of species composition dynamics on permanent observation plots in case of natural forest development}

At the first stage, in order to fix the status-quo and obtain a proper classification by species composition and structure, the objects were subjected to cluster analysis. The characteristics for cluster analysis were stand age and stock volume of four groups of species (light coniferous, pioneer deciduous, broadleaved and dark coniferous) in the parent canopy and subcanopy.

Amongst the characteristics examined, the highest contribution to object differentiation was made by the stock volume of broadleaved and dark coniferous spe- cies in the canopy (the Euclidean distance [ED] exceeding 90\%). Canopy age was less important, with the ED hardly exceeding $50 \%$, whereas the composition of the second layer had minor effect ( $\mathrm{ED}<20 \%$ ).

The cluster analysis distributed all studied objects as follows (Tab. 1).

Cluster 1. Pine and larch-predominated stands, often of cultural origin ( 22 objects), divided into four subclusters by oxalis or composite type and the presence or absence of broadleaved subcanopy

Cluster 2. Spruce-predominated stands of oxalis or composite type (12 objects) subdivided into subclusters by stand origin and the presence or absence of subcanopy

Cluster 3. Monolayered lime-predominated stands or two-layered mixed forests with lime-predominated subcanopy (10 objects). No sub-clusters were detected

Table 1. Plots arrangement according to canopy and subcanopy species composition and canopy age as the result of cluster analysis

\begin{tabular}{|c|c|c|c|c|}
\hline $\begin{array}{l}\text { Cluster } \\
\text { No. }\end{array}$ & Cluster description & $\begin{array}{c}\text { Number } \\
\text { of } \\
\text { objects }\end{array}$ & $\begin{array}{c}\text { Sub- } \\
\text { cluster } \\
\text { No. }\end{array}$ & Sub-cluster description \\
\hline \multirow{4}{*}{1} & \multirow{4}{*}{ Light coniferous stands } & \multirow{4}{*}{22} & 1.1 & $\begin{array}{l}\text { Pine stands with developed lime subcanopy, Pineta tilieta } \\
\text { composita. }\end{array}$ \\
\hline & & & 1.2 & Pine stands with oxalis cover, Pineta oxalidosa \\
\hline & & & 1.3 & Pine stands with composite herbage, Pineta composita \\
\hline & & & 1.4 & $\begin{array}{l}\text { Larch stands (cultures) with composite herbage, Lariceta } \\
\text { composita }\end{array}$ \\
\hline \multirow{3}{*}{2} & \multirow{3}{*}{$\begin{array}{l}\text { Spruce stands of oxalis or } \\
\text { composite type }\end{array}$} & \multirow{3}{*}{12} & 2.1 & Monodominant spruce cultures, Piceeta oxalidosa \\
\hline & & & 2.2 & Monolayered spruce forests of oxalis type, Piceeta oxalidosa \\
\hline & & & 2.3 & Two-layered spruce forests of composite type, Piceeta composita \\
\hline 3 & $\begin{array}{l}\text { Monolayered lime stands } \\
\text { or mixed forests with lime- } \\
\text { predominated subcanopy, } \\
\text { Tilieta composita, Querceta } \\
\text { tilieta composita }\end{array}$ & 10 & None & \\
\hline \multirow{3}{*}{4} & \multirow{3}{*}{$\begin{array}{l}\text { Birch stands of composite } \\
\text { type, Betuleta composita }\end{array}$} & \multirow{3}{*}{13} & 4.1 & Two-layered stands with monodominant birch canopy \\
\hline & & & 4.2 & $\begin{array}{l}\text { Two-layered stands with the admixture of light coniferous or } \\
\text { broad-leaved species in the canopy }\end{array}$ \\
\hline & & & 4.3 & $\begin{array}{l}\text { Monolayered stands with the admixture of light coniferous or } \\
\text { broadleaved species }\end{array}$ \\
\hline \multirow{2}{*}{5} & \multirow{2}{*}{$\begin{array}{l}\text { Mixed two-layered stands of } \\
\text { composite type. Predominating } \\
\text { species are broadleaved or } \\
\text { spruce and broadleaved }\end{array}$} & \multirow{2}{*}{12} & 5.1 & $\begin{array}{l}\text { Oak and lime stands with broad-leaved subcanopy, Tilieta } \\
\text { composita, Querceta tilieta composita }\end{array}$ \\
\hline & & & 5.2 & $\begin{array}{l}\text { Broadleaved stands with a noticeable admixture of pioneer species } \\
\text { and spruce in the canopy: Abieto-Tilieta, Betuleto-Querceta, etc. }\end{array}$ \\
\hline 6 & Unattributed objects & 5 & & \\
\hline
\end{tabular}


Cluster 4. Birch-predominated stands of composite type (13 objects), subdivided into 3 sub-clusters by the presence or absence of subcanopy and admixture of other species in the canopy.

Cluster 5. Mixed two-layered stands of composite type (12 objects). Predominating species are broadleaved or spruce and broadleaved. Divided into two sub-clusters by the percentage of spruce and/or pioneer species

Five objects could not be attributed to any of these clusters and are thus regarded separately as indefinite objects, conditional Cluster 6 .
A representation of the average composition of the classes distinguished is presented in Figure 3.

Therefore, besides the species composition of canopy, other characteristics are important for stand classification (in descending order): stand origin, forest type and vertical structure.

To determine the main directions of forest evolution and shift of species composition, four additional parameters were added to the matrix for cluster analysis: the abundance of trees of the four groups in the undergrowth, expressed as specimen per hectare.

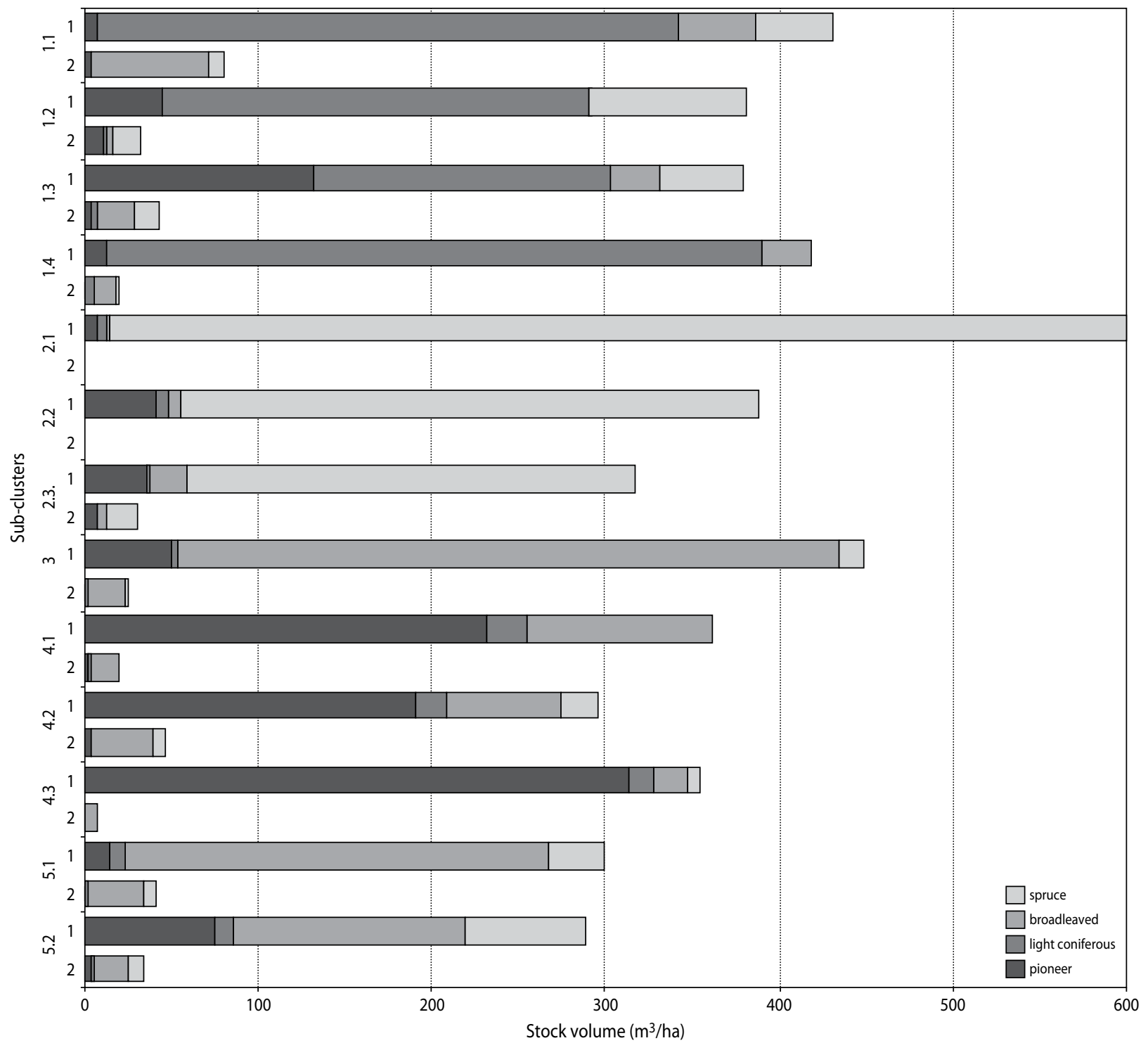

Figure 3. Composition of canopy (1) and subcanopy (2) layers of stand clusters, by species groups, expressed in $\mathrm{m}^{3} / \mathrm{ha}$ 
In this case, the abundance of broadleaved species in the undergrowth proved to be the one significant parameter providing the differentiation at $100 \%$ level.

All objects were re-grouped according to the leading characteristic, that is, abundance of broadleaved species in the undergrowth (Tab. 2).

Group 1: 13 objects. Stands with very sparse regeneration ( $360 \pm 236$ specimens/ha) represented by lime and spruce. This group unites mainly the plots of the two first clusters (coniferous forests of oxalis type).

Group 2: 13 objects; stands with sparse natural regeneration $(1,543 \pm 407$ specimens/ha) represented by lime, with episodic and single participation of other species. The group unites coniferous and birch forests, mainly of composite type

Group 3: 9 objects; stands with the number of undergrowth, which is classified as satisfactory $(2,895 \pm$ 481 specimens/ha), predominated by lime, with the admixture or single participation of other species
Group 4: 15 objects; stands with an abundant regeneration $(5,408 \pm 1453$ specimens/ha), totally predominated by broadleaved species. This group includes secondary forests, including monodominant lime stands and pine and larch cultures

Groups 5: 7 objects; deciduous stands with a significant participation of spruce in the undergrowth. Total number of undergrowth is $5,878 \pm 1,343$, spruce being $969 \pm 331$ specimens/ha. All plots are situated in Shchelkovo Forestry, which are remote from the expected effect of Moscow megacity

Group 6: 10 objects; stands with very abundant undergrowth (from 9,600 to 35,100 specimens/ha) totally predominated by maple, with minor role of lime and single participation of other species. The group unites the plots from Losiny Ostrov located near the borders of the national park with urbanized territories

Group 7: 3 objects; stands with sparse undergrowth, represented by lime and pioneer deciduous species

Table 2. Average abundance and occurrence of tree species in the undergrowth layer by undergrowth clusters, mean \pm standard deviation*

\begin{tabular}{|c|c|c|c|c|c|c|c|c|c|}
\hline \multirow[b]{2}{*}{ Group } & \multicolumn{2}{|c|}{ Pioneer deciduous } & \multicolumn{2}{|c|}{ Light coniferous } & \multicolumn{2}{|c|}{ Broadleaved } & \multicolumn{2}{|c|}{ Spruce } & \multirow{2}{*}{\begin{tabular}{|c} 
Total \\
Abundance \\
(speci- \\
mens/ha)
\end{tabular}} \\
\hline & $\begin{array}{c}\text { Abundance } \\
\text { (speci- } \\
\text { mens/ha) }\end{array}$ & $\begin{array}{c}\text { Occurrence } \\
(\%)\end{array}$ & $\begin{array}{l}\text { Abundance } \\
\text { (speci- } \\
\text { mens/ha) }\end{array}$ & $\begin{array}{c}\text { Occurrence } \\
(\%)\end{array}$ & $\begin{array}{l}\text { Abundance } \\
\text { (speci- } \\
\text { mens/ha) }\end{array}$ & $\begin{array}{c}\text { Occurrence } \\
(\%)\end{array}$ & $\begin{array}{c}\text { Abundance } \\
\text { (Speci- } \\
\text { mens/ha) }\end{array}$ & $\begin{array}{c}\text { Occurrence } \\
(\%)\end{array}$ & \\
\hline 1 & Single & 8 & 0 & 0 & $\begin{array}{c}225.8 \pm \\
125.2\end{array}$ & 100 & $\begin{array}{c}191.0 \pm \\
158.0\end{array}$ & 61 & $\begin{array}{c}359.8 \pm \\
237.6\end{array}$ \\
\hline 2 & 184 & 23 & 0 & 0 & $\begin{array}{c}1,417.4 \pm \\
357.8\end{array}$ & 100 & $\begin{array}{c}163.5 \pm \\
64.6\end{array}$ & 46 & $\begin{array}{c}1,543.0 \pm \\
407.4\end{array}$ \\
\hline 3 & 101 & 33 & 144 & 11 & $\begin{array}{c}2,682.0 \pm \\
333.6\end{array}$ & 100 & $\begin{array}{l}368 \pm \\
43.3\end{array}$ & $44 * *$ & $\begin{array}{c}2,895.3 \pm \\
480.8\end{array}$ \\
\hline 4 & 142 & 20 & 120 & 7 & $\begin{array}{c}5,362.3 \pm \\
1,144.8\end{array}$ & 100 & 77 & 13 & $\begin{array}{c}5,408.3 \pm \\
1,152.7\end{array}$ \\
\hline 5 & $\begin{array}{c}770.0 \pm \\
249.9\end{array}$ & 57 & 0 & 0 & $\begin{array}{c}4,468.6 \pm \\
1,648.8\end{array}$ & 100 & $\begin{array}{c}969.3 \pm \\
331.7\end{array}$ & 100 & $\begin{array}{c}5,877.9 \pm \\
1343.2\end{array}$ \\
\hline 6 & 195 & 30 & 0 & 0 & $\begin{array}{c}17,432.6 \pm \\
8083.2\end{array}$ & 100 & 149 & 30 & $\begin{array}{c}17,535.8 \pm \\
8,073.2\end{array}$ \\
\hline 7 & $\begin{array}{c}868.7 \pm \\
322.2\end{array}$ & 100 & 0 & 0 & $\begin{array}{c}904.3 \pm \\
575.4\end{array}$ & 100 & 80 & 33 & $\begin{array}{c}1,799.7 \pm \\
771.7\end{array}$ \\
\hline 8 & 0 & 0 & 0 & 0 & 652 & 50 & 2,432 & 100 & 3,084 \\
\hline \multicolumn{10}{|c|}{ Unattributed plots } \\
\hline plot48 & 288 & & 0 & & 1,952 & & 480 & & 2,720 \\
\hline plot56 & 0 & & 0 & & 1,800 & & 0 & & 1,800 \\
\hline
\end{tabular}

* The standard deviation was not determined for small groups (2-3 objects) and the species with a low occurrence because of insufficient number of records.

** In Shchelkovo Forestry only. 
Group 8: 2 objects with satisfactory density of undergrowth and predomination of spruce in undergrowth composition

Two more objects stand apart at the likelihood dendrogram and cannot be referred to any of enumerated groups.

By the composition and abundance of undergrowth, the eight groups represent two general directions of forest successions: demutation (or gradual restoration of late-succession species typical for the region) and nemoralisation (shift towards the domination of broad- leaved species). The demutation trend unites Groups 3,5 and 8 as having noticeable participation of spruce in the undergrowth, whereas Groups 4, 6 and 7 (and, conditionally, Group 2) are the cases of nemoralisation. The undergrowth on the plots referred to Group 1 is too sparse to determine the pattern of forest evolution.

To understand the general direction of species composition changes, we tried to find the correspondence between canopy clusters and regeneration groups.

The light coniferous forests (Cluster 1) belong to Groups 1, 2, 3 and 4 by undergrowth composition. They



Figure 4. General trends of forest evolution on the permanent observation plots, attributed to different clusters by species composition and structure. For cluster description, see Table 1

Table 3. The distribution of stand clusters by patterns of current dynamics for the territory of the national park Losiny Ostrov

\begin{tabular}{|c|c|c|c|c|c|}
\hline \multirow[b]{2}{*}{ Cluster } & \multirow{2}{*}{$\begin{array}{l}\text { Total number } \\
\text { of POP }\end{array}$} & \multirow{2}{*}{$\begin{array}{c}\text { Number of POP } \\
\text { with apparent stand } \\
\text { dynamics }\end{array}$} & \multicolumn{3}{|c|}{ Dynamics patters } \\
\hline & & & Succession & $\begin{array}{c}\text { Non-critical natural } \\
\text { disturbances }\end{array}$ & Canopy death \\
\hline 1. Pineta & 19 & 6 & 5 & 1 & - \\
\hline 2. Piceeta & 7 & 1 & - & 1 & 2 \\
\hline $\begin{array}{l}\text { 3. Tilieta; Querceta } \\
\text { tilieta }\end{array}$ & 8 & 3 & 3 & - & - \\
\hline 4. Betuleta & 10 & 5 & 4 & 1 & - \\
\hline $\begin{array}{l}\text { 5. Querceta and } \\
\text { mixed two-layered }\end{array}$ & 7 & 6 & 1 & 5 & - \\
\hline 6. Indefinite & 5 & 2 & 2 & - & - \\
\hline Total & 56 & 25 & 15 & 8 & 2 \\
\hline
\end{tabular}


either demonstrate the trend towards the nemoralisation (increasing importance of broadleaved species) or, in case of Group 1, their future is indefinite, because the number of trees in the undergrowth layer is insufficient to form the next forest generation (Fig. 4).

Seven of 12 spruce sites (Cluster 2) are not supplied by natural regeneration. In the five other sites, the un- dergrowth is represented by broadleaved species, especially in the peripheral part of the national park.

Lime forests and mixed oak-lime and spruce-lime forests (Cluster 3) either possess a satisfactory number of lime undergrowth (Groups 3 and 4) or have an extremely abundant maple undergrowth (again at the boundaries of the national park).

Table 4. Changes in the composition of the three vertical layers in case of natural development by species groups: (I) pioneer deciduous, (II) light coniferous, (III) broadleaved and (IV) spruce

\begin{tabular}{|c|c|c|c|c|c|c|c|c|c|c|c|c|c|c|c|}
\hline \multirow{2}{*}{$\begin{array}{l}\text { Forest types } \\
\text { (clusters) }\end{array}$} & \multirow{2}{*}{$\begin{array}{l}\text { Plot } \\
\text { No. }\end{array}$} & \multirow{2}{*}{ Year } & \multirow{2}{*}{ Age } & \multicolumn{4}{|c|}{ Canopy (m³/ha) } & \multicolumn{4}{|c|}{ Subcanopy $\left(\mathrm{m}^{3} / \mathrm{ha}\right)$} & \multicolumn{4}{|c|}{ Undergrowth (pc./ha) } \\
\hline & & & & $\mathrm{I}$ & II & III & IV & I & II & III & IV & I & II & III & IV \\
\hline \multirow{8}{*}{$\begin{array}{l}\text { Pineta composita } \\
(1.1,1.3)\end{array}$} & \multirow{2}{*}{5} & 1998 & 53 & 19 & 258 & 0 & 0 & & & 3 & 0,3 & 0 & 0 & 975 & 0 \\
\hline & & 2013 & 68 & 63 & 333 & 11 & 0 & 2 & 6 & 29 & 3 & 0 & 0 & 1,946 & 133 \\
\hline & \multirow{2}{*}{11} & 1998 & 63 & 25 & 528 & 0 & 0 & & & 35 & 8 & 0 & 0 & 0 & 250 \\
\hline & & 2013 & 78 & 20 & 513 & 2 & 6 & 0 & 0 & 83 & 6 & 0 & 0 & 448 & 64 \\
\hline & \multirow{2}{*}{14} & 1998 & 63 & 149 & 172 & 17 & 0 & 4 & 5 & 2 & 0,3 & 0 & 0 & 1,010 & 0 \\
\hline & & 2013 & 78 & 188 & 234 & 26 & 0 & 5 & 5 & 29 & 4 & 0 & 0 & 5,614 & 0 \\
\hline & \multirow{2}{*}{21} & 1999 & 200 & 0 & 296 & 53 & 61 & & & 45 & 0 & 0 & 0 & 5,338 & 0 \\
\hline & & 2014 & 215 & 0 & 299 & 97 & 84 & 0 & 0 & 75 & 0 & 0 & 0 & 10,928 & 208 \\
\hline \multirow{2}{*}{$\begin{array}{l}\text { Pinetum oxalido- } \\
\text { sum }(1.2)\end{array}$} & \multirow{2}{*}{22} & 1999 & 49 & 127 & 136 & 0 & 0 & 0 & & & 49 & 0 & 0 & 600 & 875 \\
\hline & & 2014 & 64 & 152 & 187 & 0 & 88 & 6 & 3 & 0 & 32 & 0 & 0 & 856 & 240 \\
\hline \multirow{2}{*}{$\begin{array}{l}\text { Quercetotilietum } \\
\text { compositum (3) }\end{array}$} & \multirow{2}{*}{20} & 1998 & 75 & 7 & 15 & 406 & 0 & 0 & 0 & 10 & 0 & 0 & 0 & 3,625 & 125 \\
\hline & & 2013 & 90 & 0 & 13 & 418 & 0 & 0 & 0 & 117 & 0 & 0 & 0 & 10,688 & 0 \\
\hline \multirow{10}{*}{$\begin{array}{l}\text { Betuleta } \\
\text { composita } \\
(4.1,4.2,4.3)\end{array}$} & \multirow{2}{*}{25} & 1999 & 90 & 198 & 50 & 8 & 0 & 0 & 0 & 73 & 7 & 0 & 0 & 17,575 & 0 \\
\hline & & 2014 & 105 & 225 & 25 & 13 & 0 & 6 & 1 & 111 & 6 & 80 & 0 & 27,048 & 160 \\
\hline & \multirow{2}{*}{42} & 2000 & 55 & 318 & 5 & 56 & 0 & 3 & 1 & 31 & 0 & 0 & 0 & 5,275 & 0 \\
\hline & & 2015 & 70 & 263 & 0 & 101 & 0 & 1 & 0 & 11 & 0 & 0 & 0 & 1,432 & 0 \\
\hline & \multirow{2}{*}{43} & 2000 & 55 & 243 & 32 & 59 & 0 & 4 & 3 & 24 & 0 & 0 & 0 & 10,863 & 0 \\
\hline & & 2015 & 70 & 229 & 55 & 97 & 0 & 2 & 1 & 31 & 0 & 280 & 0 & 14,464 & 0 \\
\hline & \multirow{2}{*}{44} & 2000 & 55 & 316 & 0 & 0 & 0 & 16 & 4 & 18 & 0 & 0 & 0 & 3,600 & 0 \\
\hline & & 2015 & 70 & 290 & 0 & 32 & 0 & 3 & 0 & 26 & 0 & 0 & 0 & 6,040 & 0 \\
\hline & \multirow{2}{*}{53} & 2000 & 50 & 234 & 93 & 0 & 0 & 0 & 0 & 41 & 0 & 0 & 0 & 7,350 & 0 \\
\hline & & 2015 & 65 & 271 & 77 & 60 & 0 & 0 & 0 & 0 & 0 & 0 & 0 & 4,256 & 0 \\
\hline $\begin{array}{l}\text { Tilietum compo- } \\
\text { situm (5.1) }\end{array}$ & 9 & 1998 & 60 & 11 & 0 & 218 & 67 & 0 & 0 & 20 & 0 & 0 & 0 & 6,250 & 0 \\
\hline \multirow{5}{*}{$\begin{array}{l}\text { Betuleta } \\
\text { oxalidosa (6) }\end{array}$} & \multirow{2}{*}{36} & 1999 & 47 & 235 & 16 & 2 & 0 & 0 & 0 & 0 & 62 & 0 & 0 & 0 & 375 \\
\hline & & 2014 & 62 & 225 & 31 & 10 & 140 & 1 & 0 & 2 & 10 & 0 & 0 & 952 & 0 \\
\hline & \multirow{3}{*}{40} & 1999 & 44 & 360 & 3 & 0 & 15 & 0 & 0 & 14 & 8 & 0 & 0 & 190 & 875 \\
\hline & & 2014 & 59 & 423 & 4 & 28 & 70 & 4 & 0 & 6 & 63 & 0 & 0 & 0 & 2,000 \\
\hline & & 2013 & 75 & 9 & 0 & 302 & 41 & 0 & 0 & 51 & 0 & 0 & 0 & 4,928 & 0 \\
\hline
\end{tabular}


Birch forests of composite type (Cluster 4) evolve towards lime ones in the national park (Groups 2 and 4) and towards mixed spruce-lime forests (Group 5) in a more remote Shchelkovo Forestry.

Two-layered broadleaved and mixed forests also evolve differently depending on the remoteness from the city. In Losiny Ostrov, the main pattern is the formation of lime subcanopy with insignificant participation of spruce or pioneer deciduous species (Groups 2, 3 and 4). In Shchelkovo Forestry, the participation of spruce in the composition of future forests is more pronounced (from $10 \%$ to $68 \%$ ) (Groups 5 and 8).

\section{5-Year dynamics of stand structure and composition}

The data listed above represent potential trends in species composition changes. Real current changes can be followed in the course of 15 years of observation in the national park.

We found that the situation was dynamic at 25 POPs of total 56 in the national park. We assumed the stand to be dynamic and the changes to be significant in case of
$10 \%$ change in a relative importance of species groups in the total stock volume and/or the increase of the subcanopy stock volume up to $10 \%$ or more of the canopy stock volume.

Three patterns of current dynamics were observed: gradual evolution (succession) in the absence of noticeable natural or human-induced disturbances, non-critical natural disturbances leading to the losses of single trees or tree groups and critical disturbances leading to the death of the whole canopy or at least predominating species of the canopy (Tab. 3).

(1) Successional dynamics in the absence of disturbances -15 of 25 dynamic plots. This pattern is absolutely typical for middle-aged pine and birch stands, rarely observed in old-growth composite forests (Tab. 4). The most apparent changes are boldfaced in the table.

(2) Natural disturbances (windfall and pest outbreaks) with partial losses in the canopy, which were referred to as non-critical. They are typical for old-growth forests, mainly broadleaved or mixed ones (Cluster 5).

Table 5. Changes in the composition of the three vertical layers in case of non-critical natural disturbances by species groups: (I) pioneer deciduous, (II) light coniferous, (III) broadleaved and (IV) spruce

\begin{tabular}{|c|c|c|c|c|c|c|c|c|c|c|c|c|c|c|c|}
\hline \multirow{2}{*}{$\begin{array}{c}\text { Forest types } \\
\text { (clusters) }\end{array}$} & \multirow{2}{*}{$\begin{array}{l}\text { Plot } \\
\text { No. }\end{array}$} & \multirow{2}{*}{ Year } & \multirow{2}{*}{ Age } & \multicolumn{4}{|c|}{ Canopy (m³/ha) } & \multicolumn{4}{|c|}{ Subcanopy (m³/ha) } & \multicolumn{4}{|c|}{ Undergrowth (pc./ha) } \\
\hline & & & & I & II & III & IV & $\mathrm{I}$ & II & III & IV & I & II & III & IV \\
\hline \multirow{2}{*}{$\begin{array}{l}\text { Pinetum } \\
\text { oxalidosum } \\
(1.2)\end{array}$} & 32 & 1999 & 95 & 43 & 220 & 0 & 194 & 5 & 4 & 0 & 21 & 0 & 0 & 0 & 0 \\
\hline & & 2014 & 110 & 26 & 204 & 0 & 105 & 3 & 3 & 0 & 27 & 0 & 0 & 432 & 440 \\
\hline \multirow{2}{*}{$\begin{array}{l}\text { Piceetum } \\
\text { compositum } \\
(2.1)\end{array}$} & \multirow{2}{*}{47} & 2000 & 95 & 21 & 0 & 25 & 346 & 12 & 0 & 19 & 0 & 0 & 0 & 1,000 & 125 \\
\hline & & 2015 & 110 & 21 & 0 & 34 & 191 & 3 & 0 & 7 & 1 & 0 & 0 & 16,712 & 0 \\
\hline \multirow{10}{*}{$\begin{array}{l}\text { Querceta } \\
\text { composita } \\
(5.1,5.2)\end{array}$} & \multirow{2}{*}{33} & 1999 & 125 & 141 & 8 & 123 & 58 & 18 & 0 & 1 & 17 & 0 & 0 & 1,400 & 0 \\
\hline & & 2014 & 140 & 110 & 5 & 104 & 42 & 13 & 0 & 11 & 21 & 500 & 0 & 600 & 80 \\
\hline & \multirow{2}{*}{34} & 1999 & 100 & 12 & 23 & 270 & 0 & 0 & 0 & 34 & 24 & 0 & 0 & 160 & 250 \\
\hline & & 2014 & 115 & 21 & 24 & 197 & 27 & 2 & 0 & 28 & 2 & 0 & 0 & 1,152 & 160 \\
\hline & \multirow{2}{*}{51} & 2000 & 105 & 28 & 0 & 248 & 28 & 0 & 0 & 40 & 17 & 0 & 0 & 3,875 & 500 \\
\hline & & 2015 & 120 & 36 & 0 & 132 & 22 & 0 & 0 & 60 & 18 & 224 & 0 & 14,342 & 80 \\
\hline & \multirow{2}{*}{52} & 2000 & 95 & 0 & 0 & 330 & 0 & 0 & 0 & 21 & 3 & 0 & 0 & 2,600 & 125 \\
\hline & & 2015 & 110 & 0 & 0 & 233 & 0 & 0 & 0 & 46 & 7 & 40 & 0 & 904 & 80 \\
\hline & \multirow{2}{*}{57} & 2000 & 95 & 215 & 0 & 83 & 0 & 9 & 0 & 32 & 0 & 250 & 0 & 3,900 & 0 \\
\hline & & 2015 & 110 & 26 & 0 & 124 & 0 & 5 & 0 & 35 & 0 & 80 & 0 & 7,480 & 0 \\
\hline \multirow{2}{*}{\begin{tabular}{|l} 
Betuletum \\
compositum \\
$(4.2)$
\end{tabular}} & \multirow{2}{*}{58} & 2000 & 55 & 304 & 0 & 0 & 1 & 0 & 0 & 39 & 0 & 600 & 0 & 2,750 & 0 \\
\hline & & 2015 & 70 & 200 & 0 & 49 & 2 & 1 & 0 & 19 & 2 & 0 & 0 & 5,030 & 0 \\
\hline
\end{tabular}


Table 6. Direction of forest development after partial or total death of the spruce element in composite spruce forests in Losiny Ostrov and Shchelkovo Experimental Forestry

\begin{tabular}{|c|c|c|c|c|c|c|}
\hline \multirow{2}{*}{ Plot No. } & \multirow{2}{*}{ Species } & \multicolumn{2}{|c|}{ Number of trees (pc./ha) } & \multicolumn{2}{|c|}{ Stock volume $\left(\mathrm{m}^{3} / \mathrm{ha}\right)$} & \multirow{2}{*}{$\begin{array}{c}\text { Undergrowth composition (pc./ha) } \\
\text { 2013-2014 }\end{array}$} \\
\hline & & $1998-2003$ & 2013-2014 & 1998-2003 & 2013-2014 & \\
\hline \multirow{6}{*}{16} & Spruce & 428 & 168 & 340 & 26 & - \\
\hline & Lime & 48 & 56 & 38 & 55 & 1,520 \\
\hline & Aspen & 36 & 8 & 38 & 11 & 1,280 \\
\hline & Maple & 80 & 92 & 25 & 27 & 18,800 \\
\hline & Oak & 8 & 8 & 17 & 20 & - \\
\hline & Total & 600 & 332 & 458 & 139 & 21,600 \\
\hline \multirow{5}{*}{17} & Spruce & 232 & 20 & 330 & 5 & - \\
\hline & Lime & 256 & 252 & 100 & 123 & 1360 \\
\hline & Birch & 24 & 4 & 38 & 15 & - \\
\hline & Maple & 48 & 60 & 11 & 25 & 8160 \\
\hline & Total & 560 & 336 & 479 & 168 & 9,520 \\
\hline \multirow{6}{*}{115} & Spruce & 510 & 5 & 446 & 0.2 & 40 \\
\hline & Lime & 60 & 90 & 42 & 33 & 2,720 \\
\hline & Pine & 15 & 10 & 9 & 8 & - \\
\hline & Birch & 15 & 15 & 12 & 13 & - \\
\hline & Oak & 5 & - & 9 & - & 40 \\
\hline & Total & 605 & 120 & 518 & 54,2 & 2,800 \\
\hline \multirow{7}{*}{118} & Spruce & 290 & 35 & 326 & 15 & 304 \\
\hline & Lime & 320 & 450 & 122 & 145 & 2,584 \\
\hline & Birch & 10 & 10 & 2 & 1 & - \\
\hline & Oak & 15 & 15 & 8 & 10 & 80 \\
\hline & Aspen & - & - & - & - & 288 \\
\hline & Maple & - & - & - & - & 288 \\
\hline & Total & 635 & 510 & 458 & 171 & 3,544 \\
\hline
\end{tabular}

Birch forests were damaged by wind in 2001; in broadleaved forests, oak suffered from leafroller (Tortrix viridana L.) in 2004; in coniferous forests, spruce was attacked by bark beetle (I. typographus L.) in 2010-2011. Partial loss of canopy trees enhanced the transition of subcanopy trees to the main canopy and development of the second layer. Most of the plots demonstrate an apparent increase in the abundance of broadleaved undergrowth (Tab. 5). Spruce stands have not demonstrated any response yet because of short time elapsed since the moment of disturbance.

(3) Canopy dieback as a result of bark beetle outbreak in mature spruce stands. A detailed analysis of species composition reveals the increasing role of Norway maple in the national park (plot numbers 16 and 17) and lime in both forestries (Tab. 6). Increasing number and stock volume of these species in the overstorey is accompanied by their absolute domination in the undergrowth.

\section{Discussion}

The observations demonstrated that the situation looks rather complicated. The forests of the Moscow region have a mosaic character; each piece of this puzzle has its own history. The direction of species composition changes seems to depend on forest type, previous forest history, remoteness from the megacity with its climatic and contamination effect and current use.

To arrange the whole diversity of studied sites, the cluster analysis was applied, which allowed us to groups all plots into five general clusters. The role of broadleaved species and spruce in the canopy composition expressed as their stock volume proved to be the most important characteristics for stand clusterisation. Thus, current forest composition is characterised by the importance of late-succession (conditionally climax) species, the ratio between boreal (spruce) and broadleaved species being important. The age proved 
to be less significant for stand grouping, probably, because all stands were older than 50 years, which is the age when vertical differentiation proceeds and undergrowth develops. Although other characteristics, such as subcanopy composition, demonstrated a low relative significance for object clusterisation, they made a certain contribution into internal structure of general clusters. For example, the stock volume of late-succession species in the subcanopy allowed us to subdivide the clusters by the complexity of vertical structure and forest type: forests of oxalis type (oxalidosa) usually have the boreal shape and those of composite type (composita) have lower layers predominated by broadleaved species, first of all, lime.

The next stage of cluster analysis, which included undergrowth composition as variables, led us to the conclusion that potential direction of species changes in the studied region is totally controlled by the presence and abundance of broadleaved species: lime and Norway maple.

Although 15 years of observation are a rather short period for forest dynamics, we managed to reveal three main patterns of forest dynamics when species composition changes occur, more or less corresponding to the types described by Angelstam and Kuuluvainen (2004) or Kuuluvainen and Aakala (2011).

(1) Gradual evolution with minor disturbances was observed in middle-aged forests of derivative type where late-succession species first form the undergrowth and then the second layer; the next stage is the gradual replacement of early succession or cultivated species by late-succession ones in the main canopy. All the three stages were represented on the plots. At the first stage, this pattern can be referred to as cohort dynamics.

(2) Species composition changes as a result of noncritical natural disturbances leading to a partial mortality of one canopy species. This pattern unites the features of gap and patch mosaic, because even within one plot, the size of openings can vary. This scenario is typical for mature forests and represents one of the mechanisms of formation of new tree generations. Partial mortality enhances the growth of subcanopy trees, a significant recruitment of broadleaved undergrowth and even appearance of light-demanding pioneer species (e.g. aspen) in the undergrowth, giving them a chance to contribute to the species diversity of new forest generations.
(3) Major disturbances leading to total mortality of predominating species of canopy and crucial changes in light conditions. This pattern was observed in mature spruce forests and led to the development of lime and maple undergrowth. Lime stands with a small proportion of oak, maple, aspen and single spruce trees tend to develop instead of affected spruce forests. Future recruitment of spruce undergrowth under the canopy of developing lime-predominated forests is doubtful because nothing similar is observed on plots at present (Korotkov et al. 2015; Kiseleva et al. 2019). In case of the affection of monodominant spruce forests, which are generally characterised by insufficient natural regeneration, sites dominated by undershrub species can be formed.

Dynamic changes in forest species composition are also common for the European forests, including the boreal ones (Shorohova et al. 2009; Terauds et al. 2011). Increasing areas of secondary deciduous forest, induced by an extensive model of forest use in the 20th century, became a serious problem far out the borders of Russia (Frelich 2002; Melekhov 2007). What we observe now is the next succession stage, the development of latesuccession species under the canopy of the pioneer ones.

The dominance of coniferous species in Germany, Sweden and Denmark has generally been observed for the past two centuries (Axelsson et al. 2002; Lindbladh et al. 2014). However, some researchers predict the reduction of spruce importance in the context of climate changes (Lasch et al. 2002; Spiecker et al. 2004).

A similar process of species composition shift was described for the composite spruce forests of the Berezinsky Reserve (Belarus) after the extensive dieback of spruce trees affected by bark beetle (Ermokhin et al. 2014) and for the forests of Eastern Canada, after the invasion of the eastern spruce budworm, which led to an increase in the proportion of broadleaved species (Bergeron and Harvey 1997).

The comparison of species composition of parent canopy, subcanopy and undergrowth would point out to potential directions of forest development. Considering that mixed spruce-broadleaved and spruce-predominated forests are regarded as conditionally climax ones for the Moscow region (Rysin 2012), we supposed that when both spruce and oak-associated broadleaved were present in lower layers, we dealt with the restoration of quasi-climax communities (demutation). This trend was 
observed on 18 of 78 plots examined, mainly in birch and mixed two-layered stands. Amongst them, only five plots refer to Losiny Ostrov, which is closer to the megacity.

A more frequent case is nemoralisation, that is, the development of new tree generations of broadleaved species only. This case was observed on 43 of 78 plots examined, including those after major disturbances, 39 of them being situated in the national park.

The general trend is towards the restoration of latesuccession species, but their diversity is rather low: lime in relatively undisturbed sites, maple at the boundaries with the city and spruce in more remote objects.

The expansion of Norway maple was observed in Losiny Ostrov only, particularly at the plots at the border with the city. Abundant Norway maple undergrowth develops under the canopy of different forests, mainly broadleaved ones, and sometimes reaches the second layer. The parental canopy species - oak and lime - are present in the undergrowth as single specimens.

The forests with the predomination of lime or maple have not been reported for the Eastern Moscow region for at least two centuries. Going deeper to the history of the national park forests, we shall see that lime stands first appeared in the forest assessment data in early 20th century (History and state... 2000). That is, broadleaved forests seem to represent rather a new phenomenon in a documented forest history, generated, as we suppose, by the mesoclimatic effect of Moscow megacity.

Russian climatologists report about the formation of the so-called heat island over Moscow in the past decades, especially pronounced in summer (Lokoshchenko 2014). Modal deviation of mean summer temperatures in the centre from those in remote points is $1.5^{\circ} \mathrm{C}$ (Grigorova 2004). The data of meteorological observations inside and outside the Moscow megacity make it possible to separate the urban component of warming from the general trend observed over the East-European plain. On the background of relative stabilisation of global warming in 2000-2015, the intensity of heat island over Moscow increased, especially in the lower atmosphere layers (Kislov et al. 2015).

Other ecosystem drivers can be changes in management practices and natural disasters. As the factors driving ecosystem changes usually interlock (McEwan et al. 2011), the total picture is quite complicated.

\section{Conclusion}

The future outlook of Moscow urban and peri-urban forests seems to be governed by the current recruitment of broadleaved undergrowth, which proceeds under the canopy of all tree species. Broadleaved species (lime and Norway maple) can either absolutely predominate in the subcanopy vegetation or co-dominate with spruce. The first case is more typical for the national park Losiny Ostrov, which is more subjected to the climatic effect of Moscow megacity. The mechanisms of this change can vary depending on age, composition and degree of disturbance of parent canopy. The most pronounced replacement of coniferous forests with the lime ones occurred at the sites where the spruce element of forest stand had died as a result of bark beetle invasion.

This trend, if being constant, would lead to crucial changes in the composition, structure and properties of regional forests. Actually, it is hard to estimate its possible consequences for their biodiversity and ecosystem services. However, modern models of forest growth will allow to simulate the process and trace the scenarios of forest management practices by taking into consideration the species composition shift observed.

\section{RefERENCES}

Abaturov, A.V., Melankholin, P.N. 2004. Natural forest dynamics at the permanent test plots in Moscow Oblast (in Russian). Grif and K Publishing, Tula, Russia.

Angelstam, P.K., Kuuluvainen, T. 2004. Boreal forest disturbance regimes, successional dynamics landscape structures - a European perspective. Ecological Bulletins, 51, 117-136.

Annenskaya, G.N. et al. 1997. Landscapes of Moscow Oblast and their current state (in Russian). Smolensk State University, Smolensk, Russia.

Axelsson, A.L., Ostlund, L., Hellberg, E. 2002. Changes in mixed deciduous forests of boreal Sweden 1866-1999 based on interpretation of historical records. Landscape Ecology, 17 (5), 403-418.

Bergeron, Y., Harvey, B. 1997. Basing silviculture on natural ecosystem dynamics: an approach applied to the Southern boreal mixedwood forests of 
Quebec. Forest Ecology and Management, 92 (1), 235-242.

Braslavskaya, T.Y., Tikhonova, E.V. 2016. The 25-years dynamics of broadleaved tree species distribution on the territory of Zvenigorodskaya Biological Station (Moscow State University) (in Russian with English summary). Proceedings of the $6^{\text {th }}$ All-Russian Conference Aerospace Methods and Geo-information Technologies in Forest Science, Forestry and Ecology. Center of Forest Ecology and Productivity, Russian Academy of Sciences, Moscow, 162-166.

Connell, J.Y., Slatyer, R.O. 1977. Mechanisms of successions in natural communities and their role in community stability and organization. The American Naturalist, 11 (982), 1119-1144.

Douda, J. et al. 2015. Vegetation classification and biogeography of European floodplain forests and alder carrs. Applied Vegetation Science, 19 (1), 147-163. DOI: 10.1111/avsc.12201

Ermokhin, M.V., Uglyanets, S.A., Vershitskaya, I.N., Ivkovich, V.S. 2013. State and dynamics of the oldgrowth spruce forests of the Berezinsky Biosphere Reserve (in Russian, with English summary). In: Proceedings of the $4^{\text {th }}$ International conference Monitoring and assessment of vegetation status (ed. A. V. Pugachevskii). March 2-5, 2013, Minsk, Belarus, 111-113.

Frelich, L.E. 2002. Forest dynamics and disturbance regimes: studies from temperate evergreen-deciduous forests. Cambridge University Press, Cambridge, UK.

Gamfeldt, L. et al. 2013. Higher levels of multiple ecosystem services are found in forests with more tree species. Nature Communications, 4, 1340. DOI: https://doi.org/10.1038/ncomms2328

Grigorova, E.S. 2004. About the mesoclimate of Moscow megacity (in Russian). Meteorologiya i gidrologiya, 10, 36-45.

History and state of Losiny Ostrov forests (in Russian). 2000. Ed. V.V. Nefed'ev. Prima-Press-M Publishing, Moscow.

Karminov, V.N., Martynenko, O.V. 2007. Methods of numeric classification in soil studies (in Russian). Lesnoj Vestnik, 7, 76-77.

Kiseleva, V.V., Korotkov, S.A., Stonozhenko, L.V., Naidenova E.V. 2019. Structure and regeneration of spruce forests as affected by forest management practices in the Moscow Region. IOP Conf. Series: Earth and Environmental Science, 226, 012042. DOI: $10.1088 / 1755-1315 / 226 / 1 / 012042$

Kislov, A., Konstantinov, P., Varentsov, M., Samsonov, T., Gorlach, I., Trusilova, K. 2015. Urban amplification of the global warming in Moscow megacity. EGU General Assembly 2015. Geophysical Research Abstracts, 17, EGU2015-5620.

Korotkov, S.A., Kiseleva, V.V., Stonozhenko, L.V., Ivanov, S.K., Naidenova, E.V. 2015. On the trends in the forest forming process in North-Eastern Moscow Oblast (in Russian with English summary). Lesotekhnicheskii zhurnal, 3 (19), 41-54.

Korotkov, S.A., Makuev, V.A., Lopatnikov, M.V., Nikitin, V.V., Sirotov, A.V., Stonozhenko, L.V. 2016. Forest-Use Issues in Moscow Region at the Beginning of the $21^{\text {st }}$ Century. Bulletin of the Transilvania University of Brasov. Series II - Forestry. Wood Industry. Agricultural Food Engineering, 9 (58), 17-24.

Kuuluvainen, T., Aakala, T. 2011. Natural forest dynamics in boreal Fennoscandia: a review and classification. Silva Fennica, 45 (5), 823-841.

Lasch, P., Lindner, M., Erhard, V., Suckow, F., Wenzel, A. 2002. Regional impact assessment on forest structure and functions under climate change - the Brandenburg case study. Forest Ecology and Management, 162, 73-86.

Lindbladh, M., Axelsson, A.L., Hultberg, T., Brunet, T.J., Felton, A. 2014. From broadleaves to spruce - the borealization of southern Sweden. Scandinavian Journal of Forest Research, 29 (7), 686-696. DOI: https://doi.org/10.1080/02827581.20 14.960893

Lokoshchenko, M.A. 2014. Urban 'heat island' in Moscow. Urban Climate, 10, 550-562.

Martynenko, O., Karminov, V., Shchepashchenko, D., Ontikov, P. 2018. The dependence of the productivity of pine forests of Moscow Experimental Forestry on soil conditions. Contemporary Problems of Ecology, 11, 807-812. DOI: 10.1134/ S1995425518070120

Maslov, A.A. 2012. Fluctuations and successions in forest communities under climate change (in Russian with English summary). Bulletin of Samara Scientific Research Center of Russian Academy of Sciences, 1 (5), 1316-1319. 
McEwan, R.W., Dyer, J.M., Pederson, N. 2011. Multiple interacting ecosystem drivers: toward an encompassing hypothesis of oak forest dynamics across eastern North America. Ecography, 34, 244-256. DOI: $10.1111 / \mathrm{j} .1600-0587.2010 .06390 . \mathrm{x}$

Melekhov, I.S. 2007. Forest Science (in Russian). Moscow Forest University, Moscow.

Rysin, L.P. 2012. Forests of Moscow Oblast (in Russian). KMK Publishing, Moscow.

Schepaschenko, D. et al. 2018. Improved estimates of biomass expansion factors for Russian forests. Forests, 9 (6), 312. DOI: 10.3390/f9060312

Shorohova, E., Kuuluvainen, T., Kangur, A., Jõgiste, A.K. 2009. Natural stand structures, disturbance regimes and successional dynamics in the Eurasian boreal forest: a review with special reference to Russian studies. Annals of Forest Science, 66 (2), 201. DOI: https://doi.org/10.1051/forest $/ 2008083$

Spiecker, H. et al. 2004. Norway spruce conversion - options and consequences. Research Report 18. Brill: Leiden, Boston, Köln.

Sukachev, V.N. 1972. Selected works. Vol. 1. Foundations of forest typology and biogeocoenology (in Russian). Nauka, Leningrad.

Terauds, A., Nikodemus, O., Brumelis, G. 2011. Seventy-year changes in tree species composition and tree ages in state-owned forests in Latvia. Scandinavian Journal of Forest Research, 26 (5), 446-456. DOI: https://doi.org/10.1080/02827581.2011.586647 